\title{
EFL Prospective Teachers' Competency in Phonological Awareness: Impact on Teaching English Reading
}

Yousef Alshaboul*

College of Education, The Hashemite University, P.O.Box 330127, Postal Code 13133, Zarqa, Jordan

Corresponding Author: Yousef Alshaboul, E-mail: yosouf@yahoo.com

\section{ARTICLE INFO}

\section{Article history}

Received: November 11, 2017

Accepted: January 27, 2018

Published: March 01, 2018

Volume: 7 Issue: 2

Advance access: February 2018

Conflicts of interest: None

Funding: None

\begin{abstract}
Deficits in EFL teachers' proficiency have surfaced recently as one of the possible factors contributing to children's reading problems at their early encounters with literacy. Phonological awareness (PA) has dominated specialists' interests well-timed with escalating reports containing more provoking evidence connecting children's reading disability with deficiencies in PA. This paper aims at investigating the impact of perceived proficiency, GPA, and gender of prospective teachers on shaping their future reading instruction detectable by prospective teachers' PA beliefs, awareness and knowledge. Towards this end, a four-section survey was administered to 158 pre-service EFL teachers. Results confirmed significant differences related to knowledge and beliefs at the expense of awareness.
\end{abstract}

Key words: EFL, Pre-service, Prospective, Teachers, Reading, Phonological awareness

\section{INTRODUCTION}

\section{Background of the Problem}

Children's awareness of language sounds has dominated the interest of reading scholars over the past few decades resulting in drawing relationships and investigating factors related to reading deficiencies (Richgels, 2001; Snow, Burns, \& Griffin, 1998). Accumulating data has linked children's reading difficulties to deficits in their ability to develop phonological awareness (PA, henceforth) during the early stages of language development. Therefore, research in psychology has concluded that children with reading difficulties would not be able to manipulate the sounds of a spoken word manifest in operations like segmenting, blending or deleting (Ehri, 1991; Goswami, 2000; Olofsson \& Niederose, 1999). Specialists have confirmed such conclusions through investigating the relationship between reading difficulties children face and their ability to detect or manipulate sounds in words (Anthony \& Farncis, 2005; Hatcher, Hulme \& Snowling, 2004; Share, 1995; Snowling, 1998; Vellutino, Fletcher, Snowling \& Scanlon, 2004). In compliance with this, the National Reading Panel (NRP) for instance in 2000 reported to the U.S. Congress the critical role of PA in sharpening reading skills, upon which the Panel called for engaging children in a rich letter-sound interaction environment.

Looking into the possible reasons contributing to children's reading failure, researchers have suggested the teacher as a factor. More recent, heated discussions have gone a step further by holding teachers accountable for children's failure in reading. Candace (2001) believes that the instruction that early readers receive in PA in the early stages of their literacy deeply affects their reading development. According to Pullen (2004), the inadequate preparation in PA contributes to deficits in reading. Hence, researchers hold the institutions of Higher Education responsible for teacher preparation accountable for the deficiencies reside within prospective teachers (Newman et al., 2011).

This study is empowered by the author's belief in the critical need for a competent teacher who is capable of not just developing reading skills but instilling love for reading. Therefore, the researcher examines three PA-related factors operationalized in knowledge, beliefs and awareness in conjunction with the pre-service EFL teacher's proficiency and GPA to uncover any possible impact for EFL prospective teachers' level of competency on teaching English reading.

\section{Introduction for the Problem}

A consensus calling for reading instructions to take place as early as possible is growing among researchers recently and becoming indisputable (Adams \& Bruck, 1995; Author, 2014 [details removed for peer review; Blachman, 2000; Bos et al., 2001; Juel, 1988). Researchers argue that the early success in learning the basic reading skills could 
save students from struggling with words later (Author, 2013 [details removed for peer review) or being labeled throughout their schooling experience (Francis et al., 1996; Snow et al., 1998). Regretfully, an unfortunate child may end up years down the road unable to read the ingredients or the expiry date on a food can just for not being lucky enough to be a reader, not lucky enough to be in the right classroom with a qualified teacher. What if your child or mine were not luck enough? Being detrimental as such, communities cannot afford leaving it for chance or luck; families need to be rest assured that their children are in good hands. Schools are compelled to do just that.

Becoming a good reader is strongly tied into developing command over the alphabets and the phonology of the target language (Adams, 1990; Author, 2014 [details removed for peer review; Share \& Stanovich, 1995; Snow et al., 1998). As literature may tell, phonemic awareness, phonics, fluency, vocabulary and comprehension are core for becoming literate; children building up these skills enjoy greater chances to improve their literacy skills (NRP, 2000). So said, children in EFL context are even in greater need to develop such skills in the target language; they need skills like blending, deleting, substituting and identifying the sounds of the target language if they are to become biliterate (Venkatagiri\& Levis, 2009).

Locally, and according to news recently released by the Ministry of Education (MOE) to the press, $22 \%$ of children in public schools are illiterate; they are below average in reading, writing and math. This strongly suggests that schools, teachers in specific, are not doing their job properly. In fact, this also hints to the low-literacy level of most freshmen since the school literacy trend by default transcends later into the university. According to personal observations and discussions with colleagues teaching English Foundation courses, freshmen students do lack the basic literacy skills in English; for example, reading sentences or paragraphs proper for their age level would be problematic. This could point out one major fact; EFL children face difficulties in becoming readers, which could be connected to improper and inadequate instruction. Hence, MOE in 2013 launched a wide-scale revision starting from considering the kindergartner education as obligatory into the public schools, forming a special committee to investigate reasons behind reading failure and even calling for changing the curriculum for the early grades. All that came as a response to 'fix' literacy and put schools back on track.

In light of the aforementioned argument, a collection of questions could be raised: How and why do children fail to read? What factors might possibly be behind this failure? Are EFL teachers part of the problem? Although there might be more than one factor sharing responsibility, there is a growing concern pointing toward classroom instruction. In the study that Author, 2016 [details removed for peer review conducted on pre-service teachers, emerging evidence portrayed pre-teachers as lacking basic knowledge needed for instructing children in reading. In a step further, the researcher has developed an interest to look into the case through investigating areas of possible deficits and connecting those with different variables like teachers' proficiency, GPA and gender.

\section{The Study Problem}

Literature attests that Arabic speakers face difficulties in learning English due to various reasons like the complexities they encounter when activating semantic, syntactic and pragmatic associations (Brown \& Hyness, 1985; Fender, 2003; Ryan \& Meara, 1991). English, a polyphonic and polygraphic language, is hard to learn for most Arab children as they need to go through processes operating at a prelexical stage in order to identify and activate a word or a lexical item (Siedenberg, 1992; Stanovich, 1994; Vellutino, Scanlon \& Tanzman, 1994). Although this knowledge is necessary for reading fluency in L2 (Eskey, 1988; MacDonald, 2000; Perfetti, 1985), EFL children hardly develop the required command on the aforementioned processes through their school experience. In the previous example, almost close to one quarter of Jordanian children in public schools are illiterate; they cannot read or write at the appropriate level (RTI International, 2012).

In fact, public rhetoric blames teachers for not being up to the challenge of teaching early graders good enough to become literate. In fact, based on personal discussions people have lost their faith in public schools, especially the early grades (KG-3). This is a stage where early learners are in critical need for a high-quality instruction that shapes their future reading skills. This could possibly be a reason why people in general prefer sending their children to private schools under the assumption that private schools are more capable of providing learners with high-quality EFL instruction, although not the researcher's concern for now.

The MOE has started teaching English in public schools as early as the first grade, a step could be considered a reflection of the increasing awareness of the importance of English language worldwide. Such a step provides early exposure to English language in order to achieve proficiency in its basic skills Author, 2013 [details removed for peer review). Although the English Language National Team (2006) expected first graders to read English up to the level and to demonstrate understanding when performing tasks and activities, those expectations were hardly met. Therefore, the MOE suggested taking it further by teaching English right from KG1, a step not applied to all public schools yet.

The public rhetoric dominating the scene claims that English language teachers are responsible for the reading deficits EFL learners suffer from. This stance is supported by a belief among university instructors claiming that English pre-service teachers lack substantial preparation in teaching English. Hence, this precautious study could attract the attention of decision makers to pay the due attention to the process of teacher preparation that shapes those pre-service teachers before meeting our children and assuming their classroom responsibilities.

\section{Importance of the Study}

The study earns its importance from its goal; to investigate reasons behind EFL children's failure in reading. In order to do that, the researcher focused on EFL pre-service teachers' competency with regard to PA, beliefs, knowledge and 
awareness and tried to draw possible relationships in order to explain future teachers' lack of knowledge. This study intends to enlighten and help decision makers make better and more informed decisions to improve the status quo of literacy in general and EFL reading skills in specific. Tibi (2005) connected phonological awareness to teachers' lack of the necessary knowledge and skills required to develop literacy at early grades.

\section{Questions of the Study}

Driven by the interest to infer any significant relationship between the suggested independent variables of the study and the dependent variables, the current study aims to answer the following three major questions:

1. Are there any statistically significant differences in pre-service EFL teachers' PA (a) beliefs; (b) awareness; and (c) knowledge according to the difference in their perceived proficiency level?

2. Are there any statistically significant differences in pre-service EFL teachers' PA (a) beliefs; (b) awareness; and (c) knowledge associated with the difference in their GPA?

3. Are there any statistically significant differences in pre-service EFL teachers' PA (a) beliefs; (b) awareness and (c) knowledge associated with gender?

\section{REVIEW OF RELATED LITERATURE}

Extant literature supports the key role of PA in developing and enhancing reading skills. A consensus is mounting up among researchers connecting reading failure to poor phonological awareness, the command over the sounds of the language. Said differently, PA could be used to predict reading achievement; to this end, Stanovich (1994) suggests that PA can predict achievement even "better than anything else that we know of, including IQ” (p. 284). Yopp (1992) concurs on the importance of a child being phonologically aware claiming it as the part that young learners are missing the most (Yopp, 1995). Hitherto, families, parent, caregivers, relatives and stakeholders have the right to questions the teaching-learning process and to check whether children do receive the proper instruction in PA that helps them to become good readers.

In order to respond to the questions, doubts and uncertainties of concerned individuals and communities, several researchers have investigated the issue through looking into the knowledge and strategies pre-service teachers should possess. This becomes crucial because it is indisputable that the teachers' knowledge and beliefs steer their practices in the classroom (McCutchen et al., 2002). Consequently, the instruction delivered to learners is tied into not just the knowledge teachers possess (Ehri \& Williams, 1995; McCutchen et al.,2002) but also into the strategies they use and the beliefs they behold to (McCutchen et al., 2002; Moats \& Foorman, 2003). Thus, in normal classrooms, students' performance is expected to improve in response to the instruction they receive. Cunningham and her colleagues (2004), when investigating teachers' beliefs and knowledge about
PA, found out that teachers' instruction is vulnerable to their perceived level of knowledge and negative perceived beliefs. Accordingly, this might backfire as a misrepresentation for phonological content matters and phonological skills resulting in weakness and deficiencies among learners. The biggest loser will be the child when turning into a poor reader.

Once Richards and Lockhart said "what teachers do is a reflection of what they know and believe" (1994, p. 29). Regardless if it is conceptual and abstract (Johnson, 1996) or declarative and procedural (Wood, 1996), the kind of knowledge and strategies teachers possess dictates the way they teach. Other educators support this stance arguing that classroom instructions and performance are the byproducts of the beliefs that teachers hold (Cheng et al., 2009).

It is worth mentioning that the beliefs, knowledge and experience teachers behold to could be inherited from their past schooling experience; an interference that could be positive or negative but definitely will shape and influence the way they teach when becoming teachers themselves (Holt-Reynolds, 1992; Kagan, 1992; Pajares, 1992). According to Kagan (1992), pre-service teachers draw on their past experience in order to accommodate the new knowledge; the influence of their experience channels the new learning to serve rather than to change or challenge their beliefs. This line of argument enjoys support from other researchers like Powell (1992), Tatto (1998) and Wubbels (1992).

Based on this, it is possible and logical at the same time to assume that the knowledge and beliefs teachers should have to bring up literate children can be the barrier that denies those children their chance to become readers; instead of being the facilitator, the teacher becomes the barrier. Literature does show evidence on teachers' deficiencies in knowledge and basic understanding; central elements and major concepts crucial for teaching reading are seriously lacking (Abbott et al., 2002; Mather et al., 2001; Troyer \&Yopp, 1990). Shocking results were announced after Moats' (1994) landmark study on 52 licensed teachers investigating their knowledge about oral and written language skills needed for teaching reading. Most participants displayed great difficulty in demonstrating fundamental skills in reading. Since then, serious research took place looking into the knowledge of early reading instruction that pre-service teachers need in order to improve and sharpen their competence and skills (Brady et al., 2009; Bishop, Brownell, Klingner, Leko, \& Galman, 2010; Kelcey, 2011; Piasta, Connor, Fishman, \& Morrison, 2009; Spear-Swerling, Brucker, \&Alfano, 2005; Spear-Swerling \& Cheesman, 2012; Washburn, Joshi, \& Binks-Cantrell, 2011a; Washburn, Joshi, \& Binks-Cantrell, 2011b).

Based on the work of some researchers (Cunningham et al., 2004; Moats \& Foorman, 2003), some worthy results emerged; in specific, there are misconceptions in the knowledge and the beliefs concerning PA beginning with the definition and ending up with the actual application. The work of many researchers prove that such misconceptions still dominating the discourse of both the pre- and in-service literacy instructors (Bos et al., 2001; Moats, 2009; Washburn et al., 2011a, 2011b). There is an abso- 
lute need for pre- and in-service educators to obtain research-based knowledge and develop beliefs accordingly in order to improve the reading abilities and skills of early learners (Moats, 2009; Morris, 2011). Otherwise, the situation will remain blurry and disturbing. If there is no clear understanding about what phonological awareness is and what skills need to be introduced and instilled, definitely our children will be left behind.

To wrap up, ignorance, lack of knowledge, and absence of practice in PA are plausible reasons behind children's poor performance in reading (Singer, 1979). Al-Hazza and the co-researchers (2008) hope that teachers may recognize the significance of including phonological awareness and language structure in their teaching, a hope empowered by a confirmation from Nettle (1998) that the beliefs of the pre-service teachers are subject to change. This possibility for change has increased based on the works of Joram and Gabriele (1998), Cabaroglu and Roberts (2000), MacDonald, Badger and White (2001) and others more. Still, this area of research calls for more studies since it witnesses a substantial shortage (Carlisle, Kelcey, Rowan, $\&$ Phelps, 2011) that becomes more critical when addressing EFL context.

\section{METHODOLOGY}

\section{Participants}

One hundred and fifty eight pre-service English language teachers enrolled in a major public university were randomly selected for voluntary participation in this study. All were intentionally selected from senior undergraduates who are about to start their teaching career. Based on their responses to the section eliciting general background information, the participants were classified into four groups according to their 4-point GPA $(2-2.50, n=15 ; 2.51-3,59, n=66 ; 3.1$ $3.50, n=59$, and 3.51-4, $n=18$ ). According to their perceived proficiency in English, participants were classified into three levels: low (9.5\%), intermediate (83.5\%) and advanced $(7.0 \%)$.

\section{Instrumentation}

A modified version of Preschool Literacy Practices Checklist (PLPC) (Burgess, Lundgren, Lloyd, Pianta, 2001) was administered in a multiple choice format. Participants were asked to identify, locate, and count sounds in words to the best they could. Participants were also asked to indicate their level of agreement regarding several statements addressing learning to read and phonemic awareness using a 5-point Likert scale.

The two-part survey began with general questions designed to collect demographic information regarding gender, academic proficiency and GPA. The second part was comprised of three sections measuring beliefs, awareness and knowledge. The knowledge part was a modified phonics pretest published in Self-Paced Phonics: A Text for Educators (Dow \& Baer, 2005). The pretest included questions from three categories of early literacy development; questions related to phonological awareness, phonics, and syllabification.

Validity was also checked for through consulting a panel of university professors and expert teachers. All the panel's recommendations and suggestions were taken seriously to modify the instrument and to bring it in its final version. For reliability purposes, the tool was administered to a group of undergraduates (pre-service teachers) in one of major universities in the country. Given the purpose of the study, a correlation coefficient of 0.84 was considered appropriate.

\section{Data Collection}

Data collection took place on the campus of a public university; the researcher arranged ahead with the instructors of the assigned classes to meet with the participants during class time for data collection. The researcher monitored the administration of the surveys in order to ensure that they surveys were completed appropriately and on a timely manner. The researcher provided the necessary explanation and help for participants and responded to their questions. Participants needed around forty minutes to complete the survey.

\section{Statistical Analyses}

Since the main purpose of the study was to investigate possible factors affecting the knowledge, beliefs and awareness of the pre-service EFL teachers in the area of phonological awareness, One Way Analysis of Variance (ANOVA) and $t$-test were used to fulfill the goal.

\section{RESULTS}

This study was motivated by the desire to find any significant effect for the PA knowledge, beliefs and awareness pre-service teachers possess on empowering learners' reading skills. Therefore, the researcher tackled the issue through investigating the differences in pre-service EFL teachers' beliefs, attitudes and knowledge of phonological awareness due to their perceived proficiency, GPA and gender. In specific, the researcher tried to answer the following three questions.

\section{Question One: Are There any Statistical Significant Differences in Pre-service EFL Teachers' PA (a) Beliefs, (b) Awareness, and (c) Knowledge According to the Differences in Their Perceived Proficiency Level?}

In order to investigate possible differences in pre-service EFL teachers' phonological beliefs, awareness and knowledge according to their perceived proficiency One Way Analysis of Variance (ANOVA) was used. Results, Table 1, revealed a statistically significant difference in the pre-service EFL teachers' beliefs $(F=3.09, p=.048)$ and knowledge $(F=3.59, p=.030)$. On the other hand, results did not yield any statistical differences in the participants' awareness due to their perceived proficiency. 
Table 1. One Way ANOVA for beliefs, awareness and knowledge by academic proficiency

\begin{tabular}{lccccc}
\hline & $\begin{array}{c}\text { Sum of } \\
\text { squares }\end{array}$ & df & $\begin{array}{c}\text { Mean } \\
\text { square }\end{array}$ & F & Sig. \\
\hline Awareness & & & & & \\
Between groups & 3.385 & 2 & 1.693 & 2.36 & 0.098 \\
Within groups & 111.326 & 155 & 0.718 & & \\
Total & 114.711 & 157 & & & \\
Knowledge & & & & & \\
Between groups & 0.126 & 2 & 0.063 & 3.59 & 0.030 \\
Within groups & 2.730 & 155 & 0.018 & & \\
Total & 2.856 & 157 & & & \\
Beliefs & & & & & \\
Between groups & 1.060 & 2 & 0.530 & 3.09 & 0.048 \\
Within groups & 26.589 & 155 & 0.172 & & \\
Total & 27.648 & 157 & & & \\
\hline
\end{tabular}

*Significant at the 0.05 level

\section{Question Two: Are there any Statistical Significant} Differences in Pre-service EFL Teachers' PA (a) Beliefs, (b) Awareness, and (c) Knowledge Associated with the Difference in Their GPA?

The same as in question one, ANOVA was used to investigate any significant difference in the phonological beliefs, awareness and knowledge of pre-service EFL teachers associated with GPA. Results, as shown in Table 2 below, again did reveal statistically significant differences in the same two variables, beliefs $(F=2.77, p=.043)$ and knowledge $(F=9.51, p=.000)$, but not awareness $(F=.46$, $p=708)$.

\section{Question Three: Are There any Statistical Significant} Differences in Pre-service EFL Teachers' Phonological (a) Beliefs, (b) Awareness, and (c) Knowledge Associated with Gender?

In order to investigate any significant differences that gender may have on the PA of pre-service EFL teachers' beliefs, awareness and knowledge ANOVA was used. Results of the analysis did not indicate any statistically significant differences in EFL teachers' beliefs, awareness, or knowledge associated with gender (Table 3).

\section{DISCUSSION}

In a world that no more reserves a place for illiterates, people have become true believers in the power of literacy in shaping and enhancing their chances for a better life. It is no longer possible to get a well-paid job in a world that is continuously witnessing unprecedented competition on employment and positions. Therefore, families and communities are keen on providing their members with better schooling and state-of-the-art instruction in order to prepare them for the challenges awaiting them few years down the road. It is a challenge for schools and academic institutions to shoulder
Table 2. One Way ANOVA for beliefs, awareness and knowledge by GPA

\begin{tabular}{lccccc}
\hline & $\begin{array}{c}\text { Sum of } \\
\text { squares }\end{array}$ & df & $\begin{array}{c}\text { Mean } \\
\text { square }\end{array}$ & F & Sig. \\
\hline Awareness & & & & & \\
Between groups & 1.026 & 3 & 0.342 & 0.463 & 0.708 \\
Within groups & 113.685 & 154 & 0.738 & & \\
Total & 114.711 & 157 & & & \\
Knowledge & & & & & \\
Between groups & 0.447 & 3 & 0.149 & 9.512 & 0.000 \\
Within groups & 2.410 & 154 & 0.016 & & \\
Total & 2.856 & 157 & & & \\
Beliefs & & & & & \\
Between groups & 1.417 & 3 & 0.472 & 2.773 & 0.043 \\
Within groups & 26.231 & 154 & 0.170 & & \\
Total & 27.648 & 157 & & & \\
\hline * Significant at the 0.05 level & & & &
\end{tabular}

up such great responsibility trying to help individuals meet their needs and fulfill their goals.

Societies used to trust schools in bringing up literate, skillful and independent individuals ready to enter the real life and contribute to the good of the hosting society and the world at large. However, this is not the case any longer; the picture becomes dark and the situation disastrous when discovering that these goals would be thwarted because the academic institutions are not up to the challenge and are not doing their job properly. Families are disappointed regarding the literacy level of their children; families believe that teachers are not teaching well enough and schools are not doing their job good enough. Accordingly, no one will, then, blame youngsters for losing faith and trust in their teachers! May be families realize the reason why their children no longer perceive schools as their favorite places, and why they no longer feel that intimacy.

This was the main driving reason behind carrying out this research: are teachers responsible for our kids' failure in becoming literate? The following paragraphs should help clearing part of this uncertainty.

Going back to the results of the first question of the study that addressed the impact of perceived proficiency level on pre-service EFL teachers' PA knowledge beliefs and awareness, it seems pre-service teachers' responses yielded some significance. The results did show pre-service EFL teachers suffering deficits in knowledge and beliefs related to teaching reading. In spite of being disappointing, this shocking truth has to be acknowledged first in order to be treated. The findings clearly show pre-service EFL teachers lacking necessary knowledge and beliefs that qualify them to get into the classroom. This result might suggest that the kind and quality of classroom instruction children are exposed to due to teachers' competency, might be partially or fully responsible for the deficiency learners suffer from in their reading.

Another point worth of mentioning is the discrepancy between what the teachers think of themselves and how much 
Table 3. One Way ANOVA for beliefs, awareness and knowledge by gender

\begin{tabular}{lccccc}
\hline & $\begin{array}{c}\text { Sum of } \\
\text { squares }\end{array}$ & df & $\begin{array}{c}\text { Mean } \\
\text { square }\end{array}$ & F & Sig. \\
\hline Mean aware & & & & & \\
Between groups & 0.037 & 1 & 0.037 & 0.051 & 0.822 \\
Within groups & 114.674 & 156 & 0.735 & & \\
Total & 114.711 & 157 & & & \\
Mean knowledge & & & & & \\
Between groups & 0.021 & 1 & 0.021 & 1.130 & 0.290 \\
Within groups & 2.836 & 156 & 0.018 & & \\
Total & 2.856 & 157 & & & \\
Mean beliefs & & & & & \\
Between groups & 0.037 & 1 & 0.037 & 0.212 & 0.646 \\
Within groups & 27.611 & 156 & 0.177 & & \\
Total & 27.648 & 157 & & & \\
\hline
\end{tabular}

* Significant at the 0.05 level.

they know about teaching reading. This becomes dangerous because the pre-service teacher becomes a victim for his own misjudgment, and this hazard definitely would transcend to his students. This is a threat for it connotes that teachers fall short of assessing their own knowledge and skills. This blurry vision of the pre-service teacher could be paraphrased in two ways; first, the pre-service teacher for real lacks the necessary knowledge that entitles him to run these classes. Second, even if we want to believe that the pre-service teacher possesses the necessary knowledge, it seems he does not know how to use it.

This line of argument calls more than one point for discussion. First, it is legitimate to ask about the reasons behind pre-service teachers' lack of knowledge. Second, what can be done in order to bridge the gap? Starting with the first point, logic necessitates looking into the programs hosting those pre-service EFL teachers and examining the degree plans responsible for shaping the knowledge and the skills of those future graduates. Simply put, it is either the quality of instruction they receive in their university classrooms, not good enough to equip them with the knowledge and skills necessary for their future career, or it is the program plan that is missing basic requirements and fundamentals to prepare them to become effective EFL teachers. In fact, both arguments have liable credentials that entitle them to introduce sound explanations.

By the same token, what is said about knowledge applies to beliefs since both are interrelated. People in general shape their beliefs in light of the knowledge they have. It is logical for the participants to show significant divergence in their beliefs due to the knowledge they lack in this dimension. In other words, because pre-service teachers lack the knowledge that entitles them to teach children how to read, they formed beliefs that accords with that shortage. Pre-service EFL teachers find themselves victims for beliefs they developed because of the incompetency they ended up with. Those teachers no longer observe PA in a positive way; they do not recognize its effect on producing good readers. Previ- ously, it was introduced that Richards and Lockhart had justified what teachers do in their classrooms as a reflection of their beliefs and knowledge. Similarly, Cheng et al. (2009) explained what teachers do inside their classroom as the byproduct of the beliefs they hold.

Although it is not always true, the tendency is that the higher the GPA is, the more knowledgeable or competent the student becomes; by the same token, lower GPA denotes individuals with less knowledge about the subject matter under discussion. Focusing on the results of the second question of this study regarding the plausible effect of GPA on PA knowledge, beliefs and awareness, data yielded results similar to the perceived proficiency. There were statistical significant differences detected between beliefs and knowledge related to GPA but not related to awareness. This confirms the belief that learners with higher GPAs are at a better advantage of obtaining knowledge and developing positive attitudes concerning PA and its role in developing learners' literacy skills, reading in specific.

Reflecting on the results, it seems that the findings of this study confirm the pre-service EFL teachers' shortage in knowledge and dominance of some negative attitudes toward PA. So saying, this is a declaration that future teachers are not getting what they need before becoming teachers. To be more specific, it seems that undergraduates in English Language Programs in an EFL context do not receive the adequate education and preparation before sending them to classrooms.

It is worth reiterating here that beliefs reflect the kind of knowledge and the level of competency an individual has in the target subject. This means that competent and knowledgeable individuals are more capable of articulating their beliefs. Since the argument in this study is about the beliefs that the pre-service EFL teachers hold about PA, it should be clear that participants would have been more entitled to develop positive beliefs about the power and the role of PA in teaching reading had they gained more solid knowledge about the subject matter.

The third part of the results targeted gender and any possible effect on pre-service EFL teachers' knowledge, beliefs and awareness. Results here did not yield any statistical significance similar to proficiency and GPA. Such results neutralize gender as a factor in determining how much participants know about, how far they are aware of and what beliefs they hold about PA. In practice, this conveys the message that being a male or a female does not make a difference when bringing up literate generations is on stake. Although this might sound awkward, still there is a need to carry out more research investigating the impact of gender on early graders' literacy, may be in combination with other factors.

\section{CONCLUSION}

This endeavor took place as a step toward putting more than one piece of the puzzle together and proposing some suggestions and recommendations. There is a growing disappointment with students' literacy level among families, stakeholders and even learners themselves and a pressing 
need to uncover the reasons behind the EFL learners' failure to read appropriately up to the level required. Becoming literate requires the interaction, cooperation and support of different parties including families, schools, decision makers and all stakeholders.

Although it is logically possible to end up with more than one factor contributing to the reading failure, this study has targeted pre-service teachers in specific. The teacher is the one adult who spends more time with the child even more than his family; the teacher supposedly directs, supervises, and facilitates the child's learning process. Among all others, the teacher is the one who has the access and the chance to affect positively or negatively the life of the child. Concerning reading, teacher's competency in phonological awareness is fundamental in steering the teaching process and developing students' literacy skills.

The findings of this study suggest pre-service teachers as contributing factors to the EFL learners' low-level performance in reading. Pre-service EFL teachers did not demonstrate positive beliefs toward the importance of PA in developing children's skills in reading. This is also true about knowledge; participants showed lack of knowledge in the basics necessary for teaching reading. This signals a gap in pre-service teachers' proficiency and readiness to teach reading. Hence, pre-service EFL teachers need not be in class until some intervention takes place to 'fix' the situation.

Although a straightforward solution lies in having a well-prepared and competent teacher, this does not happen overnight. This is a multi-step process that starts with decision makers in EFL contexts calling for a comprehensive revision for all programs responsible for EFL future teachers' preparation. This might mean to revisit the degree plans of the undergraduate programs and to make sure that all necessary courses related to EFL teachers' preparation are included. An evaluation for the quality of instruction to make sure that they receive the state-of-the-art instruction should also take place. This by default necessitates that EFL courses to only be delivered by specialists in the field; there is a concern that these classes are assigned to instructors from irrelevant areas or from different backgrounds. This urgently suggests carrying more studies targeting the quality of instruction delivered to the undergraduates.

In conclusion, this study recommends more research to be carried out investigating more areas that may contribute to EFL prospective teachers' readiness. It is also important to carry out research investigating teachers in the field and investigating the quality of the instruction they deliver to our children. More research is needed to disclose the reasons behind our children becoming illiterate.

\section{REFERENCES}

Abbot, M., Walton, C., \& Greenwood, C. R. (2002).Phonemic awareness in kindergarten and first grade.Teaching Exceptional Children, 34(4), 20-26.

Adams, M. J. (1990). Beginning to read: Thinking and learning about print. Cambridge, MA: MIT Press.

Adams, M. J., \&Bruck, M. (1995).Resolving the great debate. American Educator, 19(2), 7-21.
Al-Hazza, T. C.; Fleener, Ch., and Hager, J. 2008. Primary teachers' knowledge and knowledge calibration of early literacy practices.The Reading Matrix, 8, 1, 1-11.

Author, 2016 [details removed for peer review

Author, 2014 [details removed for peer review

Author, 2013 [details removed for peer review

Author, 2001 [details removed for peer review

Anthony, L., \& Francis, D. (2005) Development of Phonological Awareness. American Psychological Society, 14 (5), 255-258.

Bishop, A. G., Brownell, M. T., Klingner, J. K., Leko, M. M., \&Galman, S. A. C. (2010). Differences in beginning special education teachers: the influence of personal attributes, preparation, and school environment on classroom reading practices. Learning Disability Quarterly, 33, 75-92.

Bos, C., Mather, N., Dickson, S., Podhajski, B., and Chard, D. (2001).Perceptions and knowledge of preservice and inservice educators about early reading instruction. $A n$ nals of Dyslexia, 51, 1, 97-120.

Brady, S., Gillis, M., Smith, T., Lavalette, M., Liss-Bronstein, L., Lowe, E., et al. (2009). First grade teachers' knowledge of phonological awareness and code concepts: examining gains from an intensive form of professional development and corresponding teacher attitudes. Reading and Writing: An International Journal, 22, 425-455. http://dx.doi.org/10.1007/ s11145-009-9166-x.

Brown, T. L. \& Haynes, M. (1985).Literacy background and reading development in a second language. In T.H. Carr (Ed.), The development of reading skills. San Francisco: CA: Jossey-Bass.

Cabaroglu N. and J. Roberts (2000). Development in student teachers' pre-existing beliefs during a 1 year PGCE programme. System, 28, 3, 387-402.

Carlisle, J. F., Kelcey, B., Rowan, B., \& Phelps, G. (2011). Teachers' knowledge about early reading: effects on students' gains in reading achievement. Journal of Research on Educational Effectiveness, 4, 289-321. http:// dx.doi.org/10.1080/19345747.2010.539297.

Chard, D., \& Dickson, S. (1999). Phonological awareness: Instructional and assessment guidelines. Intervention in School and Clinic, 34, 261-270.

Cheng, M. M. H., Chan, K. W., Tang, S. Y. F., \& Cheng, A. Y. N. (2009).Pre-service teacher education student' epistemological beliefs and their conceptions of teaching.Teaching and Teacher Education, 25, 319-322.

Cunningham, A. E, Perry, K. E. Stanovich, K. E., \&Stanovich, P. J. (2004) Disciplinaryknowledge of k-3 teachers and their knowledge calibration in the domain of 10 early literacy. Annals of Dyslexia, 54(1).

Ehri, L. (1991). Development of the ability to read words.In R. Kamil, P. Mosenthal, \& P. Pearson (Eds.), Handbook of reading, (Vol., 2). New York: Longman.

Eskey, D. (1988). Holding in the bottom: An interactive approach to the language problems of second language readers. In P. Carrell, J. Devine, \& D. Eskey (Eds.), Interactive approaches to second language reading. New York: Cambridge University Press. 
Fender M. (2003).English word recognition and word integration skills of native Arabic and Japanese-speaking learners of English as a second language.Applied Psycholinguistics 24, 289-315.

Francis, D. J., Shaywitz, S. E., Stuebing, K. K., Shaywitz, B. A., \& Fletcher, J. M.(1996).

Developmental lag versus deficit models of reading disability: A longitudinal, individual growth curves study. Journal of Educational Psychology, 88, 3-17.

Gillet, J., Temple, C., \& Crawford, A. (2004). Understanding Reading Problems: Assessment and Instruction. Boston: Allyn and Bacon.

Goswami, U. (2000). Phonological representations, reading development and dyslexia: Towards a cross-linguistic theoretical framework. Dyslexia, 6, 133-151.

Hatcher, P., Hulme, C., \&Snowling, M. (2004). Explicit phoneme training combined with reading instructions helps young children at risk of reading failure. Journal of Child Psychology and Psychiatry, 45 (2), 338-58.

Holt-Reynolds, D. (1992). Personal history-based beliefs as relevant prior knowledge

in course work. American Educational Research Journal, 29(2), 325-49.

Johnson, K. E. (1996). The role of theory in L2 teacher education.TESOL Quarterly, 30, 4, 765-771.

Joram E. and A.J. Gabriele (1998).Preservice teacher beliefs: Transforming obstacles into opportunities. Teaching and Teacher Education, 14, 2, 175-191.

Juel, C. (1988). Learning to read and write: A longitudinal study of fifty-four children from first through fourth grade. Journal of Educational Psychology, 80, 437-447.

Kagan, S. (1992).Cooperative learning. San Juan Capistrano, CA: Resources for Teachers, Inc.

Kelcey, B. (2011). Assessing the effects of teachers' reading knowledge on students' achievement using multilevel propensity score stratification.Educational Evaluation and Policy Analysis, 33, 458-482. http://dx.doi. org/10.3102/0162373711415262.

Layton, L., Deeny, K., Upton, G., \& Tall, G. (1988). Researching and promoting phonological awareness in the nursery class. Journal of research in Reading, 19, 1-13.

Layton, L., Deeny, K., Upton, G., \& Tall, G. (1998).'A preschool training programme for children with poor phonological awareness: effects on reading and spelling' Journal of Research on Reading, Vol. 21 (1), 36-52.

Mather, N., Box, C., \& Babur, N. (2001).Perceptions and knowledge of preservice and inservice teachers about early literacy instruction.Journal of Learning Disabilities, 4,471-482.

MacDonald, J. (2000). Grammaticality Judgments in a second language: Influences of age of acquisition and native language. Applied Psycholinguistics, 21, 395-423.

MacDonald, M., Badger, R., \& White, G. (2001). Changing values: What use are theories of language learning and teaching? Teaching and Teacher Education, 17, 949-963.

McCutchen, D.; Harry, D. R.; Cox, S.\&Sidman, S.;Covill, A. E.; \&, Cunningham, A. E. 2003. Reading teachers' knowledge of children's literature and English phonology. Annals of Dyslexia, 53, 1, 23-45.

Moats, L. C. (1994). The missing foundation in teacher education: knowledge of the structure of spoken and written language. Annals of Dyslexia, 44, 81-102. http://dx.doi. org/10.1007/BF02648156.

Moats, L. C. (2009).Knowledge foundations for teaching reading and spelling.Reading and Writing: An International Journal, 22, 379-399. http://dx.doi.org/10.1007/ s11145-009-9162-1.

Moats, L.C., \&Foorman, B. R. (2003).Measuring teachers' content knowledge of language and reading. Annals of Dyslexia, 53, 23-45.

Morris, D. (2011). Interventions to develop phonological and orthographic systems. In A. McGill-Franzen, \& R. L. Allington (Eds.), Handbook of reading disability research (pp. 279-288). New York, NY: Routledge.

National Reading Panel. (2000). Teaching children to read: An evidence-based assessment of the scientific research literature on reading and its implications for reading instruction (NIH Publication No. 00-4769). Washington, DC: U.S. Government Printing Office.

Nettle E.B. (1998). Stability and change in the beliefs of student teachers during practice teaching. Teaching and Teacher Education, 14/2: 193-204.

Newman, L., Wagner, M., Huang, T., Shaver, D., Knokey, A.-M., Yu, J. (2011).Secondary school programs and performance of students with disabilities.A Special Topic Report of Findings from the National Longitudinal Transition Study-2 (NLTS2) (NCSER 2012-3000).U.S. Department of Education. Washington, DC: National Center for Special Education Research. Menlo Park, CA: SRIInternational, Available at www.nlts2.org/reports/2011_11/nlts2_report_2011_11_complete.pdf.

Olofsson, A. \&Niedersoe, J. (1999). Early language development and kindergarten phonological awareness as predictors of reading problems: From 3 to 11 years of age. Journal of Learning Disabilities, 32, 5, 464-472.

Pajares, M. F. (1992). Teacher beliefs and educational research: cleaning up a messy

construct. Review of Educational Research, 14, 5-19.Perfetti, C. (1985). Reading ability.New York: Oxford University Press.

Piasta, S. B., Connor, C. M., Fishman, B. J., \& Morrison, F. J. (2009).Teachers' knowledge of literacy concepts, classroom practices, and student reading growth. Scientific Studies of Reading, 13, 224-248. http://dx.doi. org/10.1080/1088843092851364.

Powell, R. (1992). The influence of prior experience on pedagogical constructs of traditional and nontraditional preservice teachers. Teaching and Teacher Education, 8 (3) 225-238.

Pullen, P. C. (2004). Effective practices for phonological awareness. Teaching LD HotSheet, 2, Retrieved from. http://TeachingLD.org/hot_sheets/.

Richards, J. C., \& Lockhart, C. (1994).Reflective teaching in second language classrooms. Cambridge: CUP.

Richgels, D. J. (2001).Invented spelling, phonemic aware- 
ness, and reading and writing instruction. In Handbook of early literacy research, Eds. S. B. Neuman\& Dickinson, 142-55. New York: Guilford.

RTI International. (2012). Student Performance in Reading and Mathematics, Pedagogic Practice, and School Management in Jordan. North Carolina, NC 27709-2194.

Ryan, A. \&Meara, P. (1991). The case of the invisible vowels: Arabic speakers reading English words. Reading in a foreign language, 7, 531-540.

Share, D. (1995). Phonological recoding and self-teaching: Sine qua non of reading acquisition. Cognition, 55, 151-218.

Share, D. L., \&Stanovich, K. E. (1995). Cognitive processes in early reading development: Accommodating individual differences into aodel of acquisition. Issues in Education: Contributions from Educational Psychology, 1, 1-57.

Siedenberg, M (1992). Beyond orthographic depth in reading: Equitable division of labor. In R. Frost \& L. Katz (Eds.), Orthography, phonology, morphology and meaning. Amsterdam: North-Holland.

Singer, H. (1979). Language, linguistics, and learning to read. In H. Singer (Ed.),

Reading, learning to read (pp. 34-41). Victoria, BC: Deakin University.

Snowling, M. (1998). Reading development and its difficulties. Educational and Child Psychology, 15, 44-58.

Snow, C. E., Burns, M. S., \& Griffin, P. (1998).Preventing reading difficulties in young children. Washington, DC: National Academy Press.

Spear-Swerling, L., Brucker, P. O., \&Alfano, M. P. (2005). Teachers' literacy-related knowledge and self-perceptions in relation to preparation and experience.Annals of

Dyslexia, 55, 266-296. http://dx.doi.org/10.1007/s11881005-0014-7.

Spear-Swerling, L., \&Cheesman, E. (2012).Teachers' knowledge base for implementing response-to-intervention models in reading.Reading and Writing: An International

Journal, 25, 1691-1723. http://dx.doi.org/10.1007/s11145011-9338-3.

Stanovich, K. (1991). Word recognition: Changing perspectives. In R. Barr, M. Kamil, P. Mosenthal, and P.
Pearson (Eds).Handbook of reading research (Vol. 1). New York: Longman.

Stanovich, K. (1994). "Word recognition: Changing perspectives." In Handbook of Reading Research, edited by Rebecca Barr, MichaelKamil, Peter Mosenthal, and David Pearson. New York: Longman.

Tatto, M. T. (1998). The influence of teacher education on teachers' beliefs about purposes of education, roles and practices.Journal of Teacher Education, 49, 1, 66-77.

Tibi, S. (2005).Teachers' Knowledge and Skills in Phonological Awareness in United Arab Emirates.International Journal of Special Education, 20 (1), 60-66.

Troyer, S. J., \&Yopp, H. K. (1990).Kindergarten teachers' knowledge of emergent literacy concepts.Reading Improvement, 27, 34-40.

Vellutino, F., Scanlon, D., \&Tanzman, M.(1994). Components of reading ability.In G. Lyon (Ed.), Frames of reference for the assessment of learning disabilities. Baltimore, MD: Paul H. Brookes.

Vellutino, F., Fletcher, J., Snowling, M., \& Scanlon, D. (2004). Specific reading disability (dyslexia): what have we learned in the past four decades? Journal of Child Psychology and Psychiatry, 45 (1), 2-40.

Venkatagiri, H.S. \& Levis, J.M. (2009). Phonological awareness and speech comprehensibility: An exploratory study. Language Awareness, 16(4), 263-277.

Washburn, E. K., Joshi, R. M., \&Binks-Cantrell, E. S. (2011a).Teacher knowledge of basic language concepts and dyslexia.Dyslexia, 17, 165-183. http://dx.doi. org/10.1002/dys.426.

Washburn, E. K., Joshi, R. M., \&Binks-Cantrell, E. (2011b). Are preservice teachers prepared to teach struggling readers? Annals of Dyslexia, 61, 21-43. http://dx.doi. org/10.1007/s11881-010-0040-y.

Woods, D. (1996). Teacher cognition in language teaching. Cambridge: CUP.

Wubbels, T. (1992).Taking account of student teachers' preconceptions. Teaching and Teacher Education, 8, $137-150$.

Yopp, H. (1995). “A Test for Assessing Phonemic Awareness in Young Children."The Reading Teacher, 49(1), 516-523. 